\title{
'Common Sense' or a Threat to EU Integration? The Court, Economically Inactive EU Citizens and Social Benefits
}

Rebecca Zahn*

\section{INTRODUCTION}

In Elisabeta Dano, Florian Dano v Jobcenter Leipzig ${ }^{1}$, the Court of Justice of the European Union (CJEU) ruled that an economically inactive European Union (EU) citizen who does not have sufficient resources to support herself and therefore does not fulfil the requirements set out in article 7(1)(b) of Directive 2004/38 for legal residence, was not entitled to equal treatment with nationals of the host Member State. As a result, such citizens could be denied access to non-contributory social benefits. In determining whether individuals have sufficient resources to support themselves, national authorities must take individual circumstances into account. The CJEU justified its decision by recognising that Member States must be allowed to prevent Union citizens from becoming 'a burden on the social assistance system'² of the host State.

The case, which was referred to the CJEU by a German Social Court (Sozialgericht Leipzig), comes at a time of intense public debates taking place in a number of 'old' Member States over possible ways to limit the free movement of EU citizens. Such debates have arisen in the wake of the recent EU enlargements which occurred in 2004 and 2007 and which were unprecedented in scale in the EU's history. They have led to a steep increase of inner EU migration, especially of 'new' Member State workers to 'old' Member States. Despite economic evidence pointing to 'new' Member State workers having a positive impact on the economies of their host states ${ }^{3}$, public opinion in 'old' Member States is increasingly hostile to EU migration. ${ }^{4}$ National politicians have begun to question the very concept of freedom of movement for EU citizens and legislative proposals have been implemented in a number of countries which restrict EU citizens'

\footnotetext{
* Lecturer in Law, University of Strathclyde. The author would like to thank the editor and anonymous reviewer for helpful comments. The usual disclaimers apply.

${ }^{1}$ Case C-333/13, judgment of 11 November 2014, nyr.

${ }^{2}$ Article 7(1)(b) Directive 2004/38/EC of the European Parliament and of the Council, of 29 April 2004, on the rights of citizens of the Union and their family members to move and reside freely within the territory of the Member States.

${ }^{3}$ See, for example, OECD, International Migration Outlook 2013; Centre for Research and Analysis, Assessing the Fiscal Costs and Benefits of A8 Migration to the UK, Discussion Paper Series CDP No. 18/09; European Commission, Impact of mobile EU citizens on national social security systems (October 2013). ${ }^{4}$ See European Commission, Standard Eurobarometer 83: Public Opinion in the European Union - First Results (Spring 2015) 36.
} 
rights to certain social benefits. While EU law provides various legal tools for Member States to react to problems related to the freedom of movement ${ }^{5}$, there is some uncertainty over their scope. The CJEU's decision in Dano has attempted to clarify the circumstances in which economically inactive EU citizens may claim social benefits and, in doing so, has been welcomed by policymakers and politicians. However, the judgment must nonetheless be treated with caution as it may have serious ramifications for our understanding of the scope of EU citizenship. This case note first outlines the facts of the case and summarises the opinion of the Advocate General and the judgment of the CJEU. It then considers the effects of the judgment on the interpretation of Directive 2004/38 and discusses its broader consequences. It concludes with the CJEU's unwillingness to engage with the Charter on Fundamental Rights (CFR).

\section{FACTS AND CASE HISTORY}

Elisabeta Dano and her son Florin - both Romanian nationals - have lived in Germany since November 2010. In July 2011, the city of Leipzig issued Ms Dano with a residence certificate of unlimited duration for EU nationals (unbefristete Freizügigkeitsbescheinigung) which certified June 2011 as her date of entry into Germany. Ms Dano has been neither in employment nor seeking employment during her time in Germany. Both she and her son have been living in the apartment of Ms Dano's sister who also supports them financially. Since 2011, Ms Dano has twice unsuccessfully applied for benefits in the form of basic provision (Grundsicherung), namely subsistence benefit for herself, social allowance for her son as well as a contribution to accommodation and heating costs, which are provided for under the German social code (Sozialgesetzbuch ('SGB') II). Both applications were refused by the Jobcenter Leipzig on the grounds of $§ 7(1)$ SGB II ${ }^{6}$ and $§ 23(3)$ SGB XII7 which allow authorities to deny social assistance to foreign nationals who have entered Germany either with a view to obtaining such assistance or whose right of residence is based solely on the search for

\footnotetext{
${ }^{5}$ See Regulation (EU) 492/2011 of the European Parliament and of the Council of 5 April 2011 on freedom of movement for workers within the Union; Article 48 TFEU relating to social security; Article 114(4)-(5) TFEU on protection of the working environment; and, Directive 2004/38/EC of the European Parliament and of the Council, of 29 April 2004, on the rights of citizens of the Union and their family members to move and reside freely within the territory of the Member States.

${ }^{6} \S 7(1)$ excludes "foreign nationals whose right of residence arises solely out of the search for employment and their family members" as beneficiaries.

${ }^{7} \S 23(3)$ states that "foreign nationals who have entered national territory in order to obtain social assistance or whose right of residence arises solely out of the search for employment, and their family members, have no right to social assistance."
} 
employment. In July 2012, Ms Dano brought an action before the Social Court, Leipzig (Sozialgericht Leipzig) challenging the Jobcenter's decision on the grounds that it was incompatible with EU law, in particular, article 18 TFEU $^{8}$ and article 45 TFEU $^{9}$ and the judgment in Joined Cases C-22/08 and 23/08 Vatsouras and Koupatantze ${ }^{10}$. While the Social Court agreed with the Jobcenter's decision under German law, it referred four questions to the Court of Justice of the European Union ('CJEU') in order to determine first, whether persons who wish to claim special non-contributory benefits under article 3(3) and article 70 of Regulation 883/2004 fall within the scope of article 4 of the Regulation which enshrines a principle of equality between EU nationals and nationals of a host Member State. Should the first question be answered in the affirmative, then the Social Court in its second and third questions queried whether Member States were precluded by either article 4 of the Regulation or by virtue of article 18 TFEU read in conjunction with article 20 TFEU11 from excluding EU citizens from accessing such benefits in order to prevent them from becoming an unreasonable burden on the state. In its fourth question, the Social Court questioned the applicability of the CFR to the facts of the case.

The CJEU issued its judgment on 11 November 2014. In its answer to the first question, the Court agreed with the finding of Advocate General Wathelet ${ }^{12}$ that special noncontributory cash benefits such as those at issue in this case fall within the scope of article 4 of Regulation 883/2004. Such benefits were intended for persons who are fit to work and their family members. As the objective of the benefits at issue is to provide basic provision so as to "enable its beneficiaries to lead a life in keeping with human dignity"13, they can also be classed as "social assistance" within the meaning of Directive 2004/38. Under article 7(1)(b), economically inactive EU citizens such as Ms Dano are entitled to residence in a host Member State for a period of longer than three months

\footnotetext{
${ }^{8}$ Article 18 TFEU prohibits discrimination on grounds of nationality.

${ }_{9}^{9}$ Article 45 TFEU provides for freedom of movement for workers.

10 [2009] ECR I-04585. The cases concerned job seekers who had been excluded from certain social benefits. The CJEU held that EU citizens who have established real links with the labour market of another Member State can receive social benefits which intend to facilitate access to the labour market. See also D. Damjanovic, 'Joined Cases C-22/08 \& C-23/08, Athanasios Vatsouras and Josif Koupatantze v Arbeitsgemeinschaft (ARGE) Nurnberg 900‘ (2010) 47 CMLR 847.

${ }^{11}$ Article 20 TFEU establishes citizenship of the European Union.

12 See para 45 of the Advocate General's Opinion issued on 20 May 2014.

$13 \S 1$ SGB II.
} 
provided they have sufficient resources not to become a burden on the social assistance system of the host Member State.

The CJEU then went on to examine the second and third questions together by first reiterating the fundamental nature of EU citizenship which allows EU citizens to be able to rely on the prohibition of discrimination on grounds of nationality found in article 18 TFEU and given more specific expression in article 24(1) of Directive 2004/38 and article 4 of Regulation 883/2004. Article 24(2) of Directive 2004/38 clarifies that Member States may restrict access to social assistance during the first three months of residence and, after that first period, to job seekers. As Ms Dano is not seeking employment and has been in Germany for longer than three months, she does not fall within the scope of article 24(2). Instead, she could claim equal treatment with nationals of the host Member State in accessing social benefits if her residence in Germany complies with the conditions found in the Directive ${ }^{14}$ and in particular those contained in article 7(1)(b): as an economically inactive Union citizen she must inter alia have sufficient resources to support herself and her son. Disregarding this condition would "run counter to an objective of the directive, set out in recital 10 in its preamble, namely preventing Union citizens who are nationals of other Member States from becoming an unreasonable burden on the social assistance system of the host Member State." 15 The CJEU agreed with the Advocate General's finding that "any unequal treatment between Union citizens who have made use of their freedom of movement and residence and nationals of the host Member State is an inevitable consequence of Directive 2004/38."16 Member States "must have the possibility, pursuant to article 7 [...] of refusing to grant social benefits to economically inactive Union citizens who exercise their right to freedom of movement solely in order to obtain another Member State's social assistance although they do not have sufficient resources to claim a right of residence." 17 The CJEU did however require Member States to carry out an examination on a case-by-case basis of the financial situation of individuals in order to determine whether they have sufficient resources in order to qualify for a right of residence under article 7(1)(b). ${ }^{18}$ As Ms Dano does not have sufficient means to support herself, she does not fulfil the

\footnotetext{
14 Para 69.

15 Para 74.

${ }^{16}$ See para 93 of the Opinion and para 77 of the judgment.

17 Para 78.

18 Para 80.
} 
conditions under the Directive to claim a right of residence and cannot therefore invoke the principle of equal treatment contained in article 24(1) of Directive 2004/38. According to the Court, "the same conclusion must be reached in respect of article 4 of Regulation 883/2004."19 In a final section, the CJEU addressed the question of the applicability of the CFR. As article 70 of Regulation 883/2004 expressly states that competence to lay down conditions creating the right to special non-contributory cash benefits remains with the Member States, the Member States are not, when they determine such conditions, implementing EU law. As a result, the CJEU found that it did not have jurisdiction under article 51 CFR to adjudicate on whether Member States must grant Union citizens non-contributory cash benefits which enable permanent residence. $^{20}$

\section{ANALYSIS}

While the judgment in Dano has been welcomed by policymakers, politicians and the media in Germany as not only clarifying the law but also allowing them to restrict access to benefits for those migrants who are not in employment thus preserving some national autonomy over social security systems ${ }^{21}$, the CJEU's reasoning leaves a number of questions unanswered. Based on the tone of the judgment, it is clear that the Court was acutely aware of the political debates surrounding the free movement of EU citizens which have been taking place in a number of Member States. ${ }^{22}$ In allowing Germany to restrict benefits to EU citizens such as Ms Dano, the CJEU has appeased politicians in those countries where Eurosceptic parties are gaining in popularity, such as the UK. The British Prime Minister David Cameron has praised the judgment as "simple common sense" 23 and has welcomed it as allowing the government to restrict access to noncontributory social benefits such as housing benefits and tax credits for EU citizens who are not workers, job seekers or former workers. ${ }^{24}$ At the same time, however, in denying

\footnotetext{
19 Para 83.

20 Paras 90-92.

${ }^{21}$ Der Spiegel, 'EuGH-Urteil zu Hartz IV: Europa bleibt offen - mit Einschränkung' (11 November 2014). See also W. Janisch, 'Das Prinzip Hartz' Süddeutsche Zeitung (Munich, 4 February 2015).

${ }^{22}$ See also M. Dougan, 'The Bubble that Burst: Exploring the Legitimacy of the Case Law on the Free Movement of Union Citizens' in M. Adams, H. de Waele, J. Meeusen, J and G. Straetmans (eds), Judging Europe's Judges: The Legitimacy of the Case Law of the European Court of Justice (Hart 2013) 145-153. ${ }^{23}$ BBC News, 'EU 'benefit tourism' court ruling is common sense, says Cameron' (11 November 2014) $<$ http://www.bbc.co.uk/news/uk-politics-30002138> accessed 18 March 2015.

${ }^{24}$ This forms part of David Cameron's proposals to limit access to welfare benefits for EU migrants. See BBC News, 'David Cameron's EU Speech' (28 November 2014) < http://www.bbc.co.uk/news/uk-politics$\underline{30250299>\text { accessed } 18 \text { March } 2015 .}$
} 
Ms Dano access to benefits, the judgment has the potential of creating a 'sub class' of EU citizens. Such an approach to the EU's free movement rules could undermine social cohesion across and within the EU's Member States. Moreover, upon closer inspection the judgment in its interpretation of Directive 2004/38 may not provide the clarity and legal certainty hoped for.

Directive 2004/38 grants economically inactive EU citizens a right of residence in host Member States provided (articles 6(1) and 7(1)(b)) they have sufficient resources for themselves and their family members so as not to become a burden on the State's social assistance system. Once citizens fulfil the requirements of the Directive, they are entitled to equal treatment with nationals of the host Member State. The Directive's provisions in this regard codify the CJEU's case law which, prior to the entry into force of the Directive, required economically inactive citizens "not to become an unreasonable burden on the public finances" 25 or to demonstrate either "a genuine link with the employment market of the State concerned" 26 or "a certain degree of integration into the society of the host State"27 before they could benefit from equal treatment and gain access to welfare benefits. However, neither the case law nor the Directive clarified the precise nature of when an applicant could be considered to be a 'burden'; which benefits can be regarded as social assistance; and, whether Member States could require citizens to be lawfully resident before accessing benefits.

In its judgment in Brey ${ }^{28}$, the CJEU attempted to answer some of these questions. It recognised that "the competent national authorities have the power to assess, taking into account a range of factors in the light of the principle of proportionality, whether the grant of a social security benefit could place a burden on that Member State's social assistance system as a whole."29 According to the Court, "Directive 2004/38 thus recognises a certain degree of financial solidarity between nationals of a host Member

\footnotetext{
25 Case C-184/99 Grzelczyk [2001] ECR I-6193, para 44.

${ }^{26}$ Case C-138/02 Collins [2004] ECR I-2703, paras 67-69 and Cases C-22 \& 23/08 Vatsouras and Koupatantze, paras 38-39.

27 Case C-209/03 Bidar [2005] ECR I-2119, para 57.

${ }^{28}$ Case C-140/12. For a more detailed discussion see H. Verschueren, 'Free movement or benefit tourism: The unreasonable burden of Brey' (2014) 16 European Journal of Migration and Law 147; D. Thym, 'The elusive limits of solidarity: residence rights of and social benefits for economically inactive Union citizens' (2015) 52 CMLR 17; A.P. van der Mei, 'Brey: residence and the concept of social assistance' (2014) 16 EJSS 73.

29 Para 72.
} 
State and nationals of other Member States, particularly if the difficulties which a beneficiary of the right of residence encounters are temporary."30 Member States remain free to determine the conditions which economically inactive EU citizens must meet in order to be classified as having 'sufficient resources'. However, in assessing individual applications, national authorities must carry out "an overall assessment of the specific burden which granting [a] benefit would place on the national social assistance system as a whole, by reference to the personal circumstances characterising the individual situation of the person concerned." 31 While Brey provided some limited guidance on the nature of the assessment which national authorities must carry out when deciding applications for benefits, the Court failed to define when a citizen becomes a 'burden'.

In Dano, the CJEU held that economically inactive EU citizens are only entitled to equal treatment with nationals in respect of access to benefits once they fulfil the residence conditions contained in the Directive. The level of 'sufficient resources' for this purpose is to be determined in the light of individual circumstances without taking into account the social benefits claimed. In comparison to Brey, the Court did not refer to financial solidarity between Member States but instead referenced recital 10 of the preamble ${ }^{32}$ of the Directive to justify its decision to make the right to equal treatment conditional upon fulfilling the residence criteria contained in the Directive. ${ }^{33}$ By simply referring to an individual assessment, the judgment in Dano accords Member States a wider margin of discretion than Brey and simplifies the number of criteria that national authorities need to take into account. Such an approach is highly unsatisfactory from the point of view of legal certainty. ${ }^{34}$ The Court has also created the paradox that economically inactive citizens may only apply for benefits if they have sufficient resources to support themselves. Yet citizens who have sufficient resources are unlikely to claim or need social assistance. The CJEU neither clarifies whether citizens who do not have sufficient resources are automatically considered to be a burden nor does it set the parameters of

\footnotetext{
30 Ibid.

31 Para 64.

${ }^{32}$ Recital 10 states that: "Persons exercising their right of residence should not, however, become an unreasonable burden on the social assistance system of the host Member State during an initial period of residence. Therefore, the right of residence for Union citizens and their family members for periods in excess of three months should be subject to conditions."

33 Para 74.

${ }^{34}$ S. O'Leary, 'The curious case of frontier workers and study finance: Giersch' (2014) 51 CMLR 601, 621622.
} 
what constitutes 'sufficient resources' even though article 8(4) of Directive 2004/38 which the Court does not cite - could have provided some guidance in this respect. Instead, the Court follows the approach of the Advocate General which allows Member States to refuse "social benefits to economically inactive Union citizens who exercise their right to freedom of movement solely in order to obtain another Member State's social assistance benefits although they do not have sufficient resources to claim a right of residence." 35 This means that those citizens who enter a country as 'benefits tourists' can, if they apply for social assistance, be automatically considered as constituting a burden on the host State and can be denied assistance. Such an approach is problematic for a number of reasons.

First, it creates an automatic right of refusal - in cases where a citizen's sole purpose for moving is to obtain social assistance - without recourse to a proportionality test (like in Brey) or "genuine link" test (as in previous case law). The Court does not, however, explain how national authorities are to objectively determine such specific situations of 'benefit tourism'. When, for example, does an individual move solely with the purpose of obtaining social assistance rather than for reasons of family reunification? In Ms Dano's case it was assumed on the basis of her lack of integration into German society that she had entered the country solely with a view to obtaining social assistance. This was the case even though she had first entered Germany in 2009, had not applied for social assistance until 2011, and had been living with her sister who also financially provided for Ms Dano and her son. The Advocate General suggested that the additional absence of any attempt to seek employment indicated that Ms Dano would have recourse to the social assistance indefinitely. ${ }^{36}$ It is regrettable that the Court did not elaborate on the Advocate General's discussion of the issue to provide more detail on how national authorities should ascertain an individual's motive in these circumstances. Lack of guidance to determine when an applicant falls into such a category may, in the increasingly politicised environment of EU free movement law, lead to national authorities applying subjective criteria which in turn would lead to different standards being applied in different states.

\footnotetext{
35 Para 78. See further H. Verschueren, 'Preventing "Benefit Tourism" in the EU: A Narrow or Broad Interpretation of the Possibilities offered by the ECJ in Dano' (2015) 52 CMLR 363.

36 Para 134.
} 
Second, the Court's approach conflicts with its previous case law on the free movement of workers where it has held that the motives underlying an individual's decision to exercise their Treaty rights were of no relevance provided he "pursues or wishes to pursue an effective and genuine activity." 37 While the Court, unlike a number of Advocates General ${ }^{38}$, has never applied the same reasoning to economically inactive EU citizens, it is now clear that different rules apply when there may be a possibility of abuse in the latter case. In treating workers and economically inactive EU citizens differently, the CJEU is dismantling the all-encompassing nature of EU citizenship.

EU citizenship, as a fundamental right without the need for any exercise of an economic activity $^{39}$ is guaranteed by the Treaty (articles 20-21 TFEU) and confirmed by the case law of the CJEU. In Grzelczyk ${ }^{40}$, the Court held that Union citizenship is destined to be the fundamental status of nationals of the Member States which includes a general right to equal treatment in law $^{41}$ and a prohibition of discrimination on grounds of nationality. ${ }^{42}$ It has been suggested that the principle has constitutional status in EU law. ${ }^{43}$ However, in contrast to earlier decisions of the Court - which had progressively expanded the scope of EU citizenship to grant economically inactive EU citizens a directly effective and autonomous right to move and reside derived from article 20 TFEU - the judgment in Dano clearly shows the limits of EU free movement law and EU citizenship. It has long been recognised that there are different categories of EU citizens (e.g. workers, students) to whom different rules apply. This is reflected in the provisions of Directive 2004/38. However, the principle of equal treatment enshrined in article 18 TFEU has been used by the Court in the past to mitigate any differences in entitlement to rights which may arise by virtue of different statuses. ${ }^{44}$ In this context, Directive 2004/38 was adopted with the aim of consolidating and protecting citizens' rights to freedom of

\footnotetext{
37 Case 53/81 Levin [1982] ECR 1035, para 23; Case C109/01 Akrich [2003] ECR I-9607, para 55; Case C127/08 Metock [2008] ECR I-6241, para 75; Case C-202/13 McCarthy II, judgment of 18 December 2014, nyr, para 54 .

${ }^{38}$ See A.G. Jacobs in Case C-147/03 Commission v Austria [2005] ECR I-5969, para 19 and A.G. Geelhoed in Case 209/03 Bidar, para 19.

${ }^{39}$ See e.g. Opinion of A.G. Colomber in Case C-65/95 Shingara [1997] ECR I-3341, para 34.

40 Para 31. This paradigm has been repeated in numerous subsequent cases. See inter alia Case C-413/99 Baumbast [2002] ECR I-7091; Case C-200/02 Zhu and Chen [2004] ECR I-9925; Case C-135/08 Rottmann. ${ }^{41}$ See inter alia Grzelczyk; Case C-224/98 D'Hoop [2002] ECR I-6191; Case C-148/02 Garcia Avello [2003] ECR I-11613; and Case C-138/02 Collins.

42 See Dano para 59.

43 Opinion of A.G. Wahl in Case C-507/12 Saint-Prix, judgment of 25 August 2014, nyr, para 2.

${ }^{44}$ See further N. Nic Shuibhne, 'Limits Rising, Duries Ascending: The Changing Legal Shape of Union Citizenship’ (2015) 52 CMLR 889.
} 
movement; confirmed by the CJEU. ${ }^{45}$ Thus, in Metock, the CJEU identified the Directive's objective as being "to facilitate the exercise of the primary and individual right to move and reside freely." 46 In Lassal, the CJEU confirmed that the Directive strengthens Union citizens' primary and individual right to free movement (citing Metock); the provisions cannot therefore be interpreted restrictively nor may they be deprived of their effectiveness. ${ }^{47}$ The Court also referred to article 45 CFR in support of this interpretation. While there has been a shift in recent case law from "predominantly rights-opening to predominantly rights-curbing assessments of citizenship rights"48, even the Court in Brey, while recognising the limits of EU citizenship rights, affirmed the objective of Directive 2004/38 as being "to facilitate and strengthen the exercise of Union citizens' primary right to move and reside freely within the territory of the Member States." 49 In Dano, on the other hand, the Court did not discuss the citizenship provisions in the Treaty but limited itself to an interpretation of article 24 of the Directive which it used to deny economically inactive EU citizens the right to equal treatment if they do not fulfil the conditions of residence. As Nic Shuibhne points out, the provisions of the Directive thus "no longer temper equal treatment rights [contained in the Treaty]; they constitute the rights." 50 Such an approach reverses the objective of the Directive $^{51}$ and, on a broader level, raises fundamental questions about our understanding of the Treaty as the constitutional boundary around both Union and State action in situations that fall within the scope of Union law." 52 For Thym, this suggests that the Court has "effectively reactivated the traditional notion of 'market citizenship', which concentrates on those who engage in transnational economic activities. In this respect, Union citizenship remains incomplete, if its promise of equality does not extend to all those who have the status." 53

\footnotetext{
${ }^{45}$ According to the Court, the Directive must also not be interpreted restrictively. See Case C-127/08 Metock and Case 162/09 Taous Lassal [2010] ECR I-09217.

46 Para 82. See also para 59 and 84.

47 Paras 30-31.

48 Nic Shuibhne, n 44 above, 902. She considers Case C-434/09 McCarthy as the starting point for this shift. ${ }^{49}$ Para 71.

50 N. Nic Shuibhne, n 44 above, 909.

51 Thym, n 28 above, 25.

52 N. Nic Shuibhne, 'Editorial - Stateless' (2014) ELR 1, 1. For a more detailed discussion of this idea see N. Nic Shuibhne, n 44 above, 907-911.

53 Thym n 28 above. For a discussion of the concept of 'market citizen' see Niamh Nic Shuibhne, 'The resilience of EU market citizenship' (2010) 47 CMLR 1597.
} 
The judgment is also problematic if one considers the practical consequences of the CJEU's decision for Ms Dano. The Court does not deal with the interaction between the 'sufficient resources' criterion and possible expulsion of EU nationals. The Court recognises that Ms Dano's lack of sufficient resources means that she cannot claim a right of residence and equal treatment in Germany under Directive 2004/3854 but it does not clarify whether this would allow a host Member State to expel an economically inactive Union citizen in these circumstances. Article 14(3) of the Directive expressly states that expulsion shall not automatically result from a Union citizen's recourse to social assistance. Similarly, the procedural guarantees surrounding articles 27-31 of Directive 2004/3855 render expulsion difficult. The Court also does not exclude Ms Dano from the scope of the Directive but merely from the principle of equal treatment ${ }^{56}$ which indicates that the procedural safeguards surrounding expulsion are still applicable. National authorities must therefore apply a proportionality test to decide whether citizens who do not have sufficient means to support themselves should be deported (which is unlikely to happen ${ }^{57}$ ) or whether they may remain in the country. The latter option has the potential of creating a 'sub-class' of impoverished EU citizens who are tolerated within the host Member State but do not have sufficient resources to support themselves and are thus denied equal treatment with nationals in accessing social benefits. This quite clearly contradicts the EU's commitment to combat social exclusion ${ }^{58}$ and has the potential to undermine social cohesion across and within the EU's Member States which may, in the longer term, threaten EU integration as such citizens are marginalised within their host societies and singled out as negative examples of the EU's rules on freedom of movement. Actual or perceived mass migration

\footnotetext{
54 Para 81.

55 These provisions contain the rules on expulsion along with guarantees which codify existing CJEU and European Court of Human Rights jurisprudence. See inter alia Case 30/77 Bouchereau [1977] ECR 1999; Cases C-482 and 493/01 Orfanopoulos [2004] ECR I-5257; App No 54273/00 Boultif v Switzerland, judgment of 2 August 2001; Case 48/75 Royer [1976] ECR 497; Case 131/79 Santillo [1980] ECR 1585. In addition, any expulsion decision must comply with the principle of proportionality. See Preamble 16 of Directive 2004/38 which the Court cited in Brey but not in Dano. See also E. Guild, S. Peers and J. Tomkin, The EU Citizenship Directive. A Commentary (OUP, Oxford 2014) 175.

${ }^{56}$ For a more detailed analysis see S. Peers, 'In light of the Dano judgment, when can unemployed EU citizens be expelled?' (EU Law Analysis, 12 November 2014)

<http://eulawanalysis.blogspot.co.uk/2014/11/in-light-of-dano-judgment-when-can.html>accessed 18 March 2015.

57 See J. Shaw and N. Nic Shuibhne, 'General Report' in U. Neergaard, C. Jacqueson and N. Holst Christensen (eds), Union Citizenship: Development, Impact and Challenges. The XXVI FIDE Congress in Copenhagen, 2014. Congress Publications, vol. 2 (DJOF Publishing, Denmark 2014) 90-93.

58 See article 3(3) TEU, article 9 TFEU, article 34(3) Charter of Fundamental Rights and target 5 of Europe 2020.
} 
following the enlargements has already resulted in "opposition to the EU [becoming] increasingly embedded both at European and national levels" which has "propelled the EU into an unprecedented phase of uncertainty, contributing to deeper and more embedded Euroscepticism with the potential to cause irreparable damage to the EU's quest for legitimacy and stability." ${ }^{59}$ While the judgment in Dano has been welcomed by politicians in a number of Member States as allowing them to exclude EU citizens from access to social benefits, its long-term consequences may be more damaging if it creates an impoverished class of citizens which undermine social cohesion within the Member States.

Finally, the judgment is disappointing in respect of the CJEU's unwillingness to engage with the CFR. As EU law does not lay down the conditions creating and defining the right to the benefits in question - competence lies with the Member States - the Court found that the CFR did not apply. At first glance, by refusing Ms Dano equal treatment in access to benefits and recognising that she did not have a right to reside in Germany under the Directive, the CJEU denied the application of EU law to the applicant in the case. It thereby follows that the CFR should not apply. Article 153(2) TFEU allows the EU to adopt minimum requirements in the area of social security and social protection of workers. This provision has never been used and Member States retain sovereignty in the sphere of social protection. Nonetheless, Member States are not immune from complying with EU law when regulating in this area. In Kohll60, the Court confirmed that while Member States are free to organise their social security systems, they must comply with EU law when exercising these powers; this is particularly the case in relation to the Treaty's provisions on the free movement of persons. ${ }^{61}$ Verschueren argues that "in Dano the [CJEU] defines the possibilities the Member States have to abstain from applying the equal treatment provisions to Union citizens claiming social benefits." As such, Member States must comply with EU law when granting EU citizens' access to social benefits. Refusal of such benefits on the grounds of the Directive for him "is

\footnotetext{
${ }^{59}$ S. Usherwood and N. Startin, 'Euroscepticism as a Persistent Phenomenon' (2013) JCMS 1, 1-2.

${ }^{60}$ Case C-158/96 Kohll [1998] ECR I-1931 at paras 17-19.

${ }^{61}$ Case C-228/07 Petersen, para 42. See also Case C-135/99 Elsen [2000] ECR I-10409, para 33, and Case C-227/03 van Pommeren-Bourgondiën [2005] ECR I-6101, para 39.
} 
definitely part of the implementation of EU law and should therefore respect the provisions of the EU Charter." 62

On a broader level, the CJEU's unwillingness to engage with the CFR's provisions limits the usefulness of its rights. The CFR's scope is broader than the general principles provided under EU law and it has been suggested that a progressive interpretation by the CJEU may result in the discovery of new general principles. ${ }^{63}$ Application of the CFR, particularly article 1 which guarantees human dignity, to the facts of the case could have fundamentally altered its outcome especially if the CJEU had taken an approach similar to that of the European Court of Human Rights (ECtHR). ${ }^{64}$ In its recent case law, the ECtHR has recognised that a State may be obliged to provide support to an individual in situations of serious deprivation or want incompatible with human dignity. ${ }^{65}$ Similarly, in Tarakhel $v$ Switzerland ${ }^{66}$, the ECtHR confirmed that states have a duty to provide shelter and basic social services to asylum seekers, especially families with small children. While Ms Dano and her 5 year old son, as EU citizens, are not limited, like the asylum seekers in Tarakhel, by an inability to return to their home countries, their stay in Germany following the ruling in Dano is precarious; they are "'illegal' EU migrants without free movement rights" 67 and are at risk of living in poverty. ${ }^{68}$ With the CJEU taking a restrictive approach to EU free movement rights, the ECtHR may be an alternative route for EU citizens deprived of their right to equal treatment under the Directive.

\section{CONCLUSION}

At a time when public opposition to the EU is growing across the Member States, the judgment in Dano makes political sense. In deciding that economically inactive EU citizens must fulfil the criteria for lawful residence contained in Directive 2004/38 before being entitled to equal treatment with nationals of the host state, the CJEU has avoided pouring fuel into the fire by tempering the debate surrounding the free

\footnotetext{
62 Verschueren, n 35 above, 387. See also K. Lenaerts, 'Exploring the Limits of the EU Charter of Fundamental Rights', (2012) 8 ECLR 375 where he discusses the scope of article 51 CFR.

63 Ibid, 386.

${ }^{64}$ For a discussion of the interaction between the rights contained in the ECHR and the CFR see ibid.

65 Application No. 30696/09, M.S.S. v. Belgium and Greece, paras 252-3.

${ }^{66}$ Application No. 29217/12, paras 94-99.

67 D. Thym, 'When Union citizens turn into illegal migrants: The Dano case' (2015) ELR 249, 262.

${ }^{68}$ See M. Koch, 'Armutsmigration belastet deutsche Städte' Deutsche Welle 20 January 2013.
} 
movement of EU citizens which is raging in a number of Member States. However, the judgment is unsatisfactory from the point of view of legal certainty and fails to engage with the consequences of its findings for national authorities and economically inactive EU citizens. The approach has the potential to create a 'sub class' of EU citizens who are living in a host Member State without being entitled to equal treatment with nationals; in effect undermining social cohesion across the EU. Finally, by redefining the scope of EU citizenship in this way, the CJEU is undermining the Grzelczyk ${ }^{69}$ paradigm whereby EU citizenship is the fundamental status of citizens of the Member States. The Court has the opportunity to reconsider these issues in a number of pending cases ${ }^{70}$ and it is to be hoped that these will enable it to clarify its case law.

\footnotetext{
${ }^{69}$ See also D. Kostakopoulou, 'Ideas, Norms and European Citizenship: Explaining Institutional Change' (2005) MLR 233; J. Shaw 'The constitutional development of citizenship in the EU context: with or without the Treaty of Lisbon' in I. Pernice, E. Tanchev (eds), Ceci n'est pas une Constitution - Constitutionalisation without a Constitution? (Nomos, 2009); and, N. Nic Shuibhne, Legal implications of EU enlargement for the individual: EU citizenship and free movement of persons, Paper presented at the ERA-Forum, 2004.

${ }^{70}$ Case C-67/14 Alimanovic; C-19/14 Talasca and C-308/14 Commission v UK.
} 